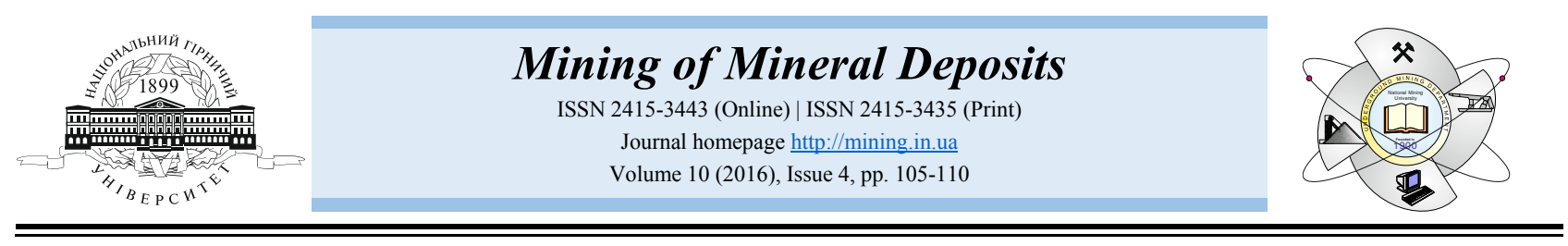

UDC 539.37/38

https://doi.org/10.15407/mining10.04.105

\title{
CUTTING-EDGE INDUSTRIAL TECHNOLOGY OF MINING TOOL MANUFACTURING
}

\author{
Iu. Savchenko ${ }^{1 *}$, A. Gurenko², O. Naumenko ${ }^{3}$ \\ ${ }^{l}$ Department of Mining Engineering, National Mining University, Dnipropetrovsk, Ukraine \\ ${ }^{2}$ Manager, LLC "VF Consulting Services", Kyiv, Ukraine \\ ${ }^{3}$ Department of Structural, Theoretical and Applied Mechanics, National Mining University, Dnipropetrovsk, Ukraine \\ *Corresponding author: e-mail SavchenY@ua.fm, tel.+380562471443, fax: +380562470835
}

\section{ПРОГРЕСИВНА ПРОМИСЛОВА ТЕХНОЛОГІЯ ВИГОТОВЛЕННЯ ГІРНИЧОГО ІНСТРУМЕНТУ}

\author{
Ю. Савченко ${ }^{1 *}$, А. Гуренко ${ }^{2}$ О. Науменко ${ }^{3}$ \\ ${ }^{l}$ Кафедра технології гірничого машинобудування, Начіональний гірничий університет, Дніпропетровськ, Украӥна \\ ${ }^{2}$ Менеджер, ТОВ “Ві Еф Консалтинг Сервіс”, Київ, Україна \\ ${ }^{3}$ Кафедра будівельної, теоретичної та прикладної механіки, Начіональний гірничий університет, Дніпропетровськ, Украӥна \\ *Biдповідальний автор: e-mail SavchenY@ua.fm, тел. +380562471443, факс: +380562470835
}

\begin{abstract}
Purpose. To conduct a comparative economic analysis of cermet alloys regeneration technology, to identify the most "environmentally friendly" and cost-effective processing of solid alloys waste.

Methods. As a research technique, the present article considers analysis of current methods of solid tungsten cobalt alloys regeneration: pyro and hydro metallurgical, chemical (chlorine, zinc), thermochemical and the method which uses energy of blasting explosives.

Findings. A comparative economic analysis of cermet alloys regeneration technologies was conducted.

Originality. Fundamental way of shock wave treatment to stimulate destruction of powder product of any configuration in order to obtain a high quality powder for further formation, sintering and tool manufacturing of multiple use is demonstrated; ecologically friendly technology of hard alloys and cermet components of outdated military hardware and ammunition recycling has been developed.

Practical implications. Industrial implementation of the developed technology allows to solve the following issues:

- utilizing super hard metal and alloys scrap for subsequent regeneration, which ensures significant savings of strategic raw material;

- the use of new technology, which excludes ineffective ways of scarce raw materials processing and manufacturing products satisfying international standards;

- gradual reduction of import in favor of hard alloys cermet tools;

- reduction and subsequent abandonment of strategic metals and alloys scrap export, shifting towards the export of ready products - powders and tools, which will significantly increase foreign currency earnings in the country.
\end{abstract}

Keywords: tungsten, cobalt, tool, hard alloy, cermet, recycling, heterogeneous medium, defect formation

\section{INTRODUCTION}

Mining minerals and the resulting waste are among principal factors which contribute to the environment pollution. Industrial and household waste of metals, especially heavy and rare, in the form of soluble salts, falling into water basins (rivers, lakes, underground aquifers), pose a serious threat to human health, flora and fauna. Therefore, two major ways to reduce ore mining is utilization and recycling of its waste - industrial salvage.
The largest source of secondary tungsten is hard alloys production, which accounts for more than a half of consumed tungsten.

Hard alloy powder is used to manufacture tools for metallurgical and engineering industry. At the moment, scrap of super hard metals is being exported to Russia, and tools are purchased by Ukrainian import companies. Production capacities of metal scrap recycling and hard alloy powder tools manufacturing allow to produce high quality product in Ukraine. The need of Ukraine for hard alloy powders is estimated at $600-700$ tons per year. 
There is a high deficiency of main components for hard alloys manufacturing such as tungsten, cobalt and nickel. Currently, hard alloys scrap in Ukraine can compensate the raw material shortage for hard alloy manufacturing by up to $50 \%$. Due to highly increased necessity of secondary tungsten usage, it is extremely important to develop an effective technology for its recycling.

Current methods of hard alloys recycling comprise dozens technological stages. Despite continuous process and equipment upgrading, each stage suggests inevitable consumption of raw products and materials, as well as comparatively high product loss and reagent emission. Some of the lost product and waste pollute the environment, therefore, while choosing recycling technology it is necessary to consider scrap origin, purification and homogeneity.

\section{THE MAIN PART OF THE ARTICLE}

There are several methods of hard tungsten cobalt alloys scrap regeneration: pyro- and hydrometallurgical, chemical (chlorine, zinc), thermochemical and using energy of blasting explosives. First two methods are very complicated, multi-staged and labori- ous, utilizing equipment which is stable in aggressive media and consuming a lot of power. Final products of these methods are composite compounds of tungsten, which require additional processing. Besides, all of these imply harmful work conditions and contamination of the environment.

Hydrometallurgical technology consists in alloying scrap and niter with consequent leaching of the alloy in diluted solution of sodium tungsten. Consequent stages replicate the process of tungsten concentrates processing. This method makes it possible to obtain tungsten anhydrate and cobalt oxide of high purification. This method is irreplaceable when processing heterogeneous scrap containing admixtures (unsoldered plates, different grades of alloys, etc.).

Oxidation-reduction method is of interest because it uses the same type of equipment as is used for hard alloys production. The approach presupposes that lump scrap (thoroughly purified, $\mathrm{WC}+\mathrm{Co}$ grade) is oxidized, milled and reduced, extracting tungsten and cobalt compound. The obtained compound is carbonized and processed by the typical technology of hard alloys manufacturing.

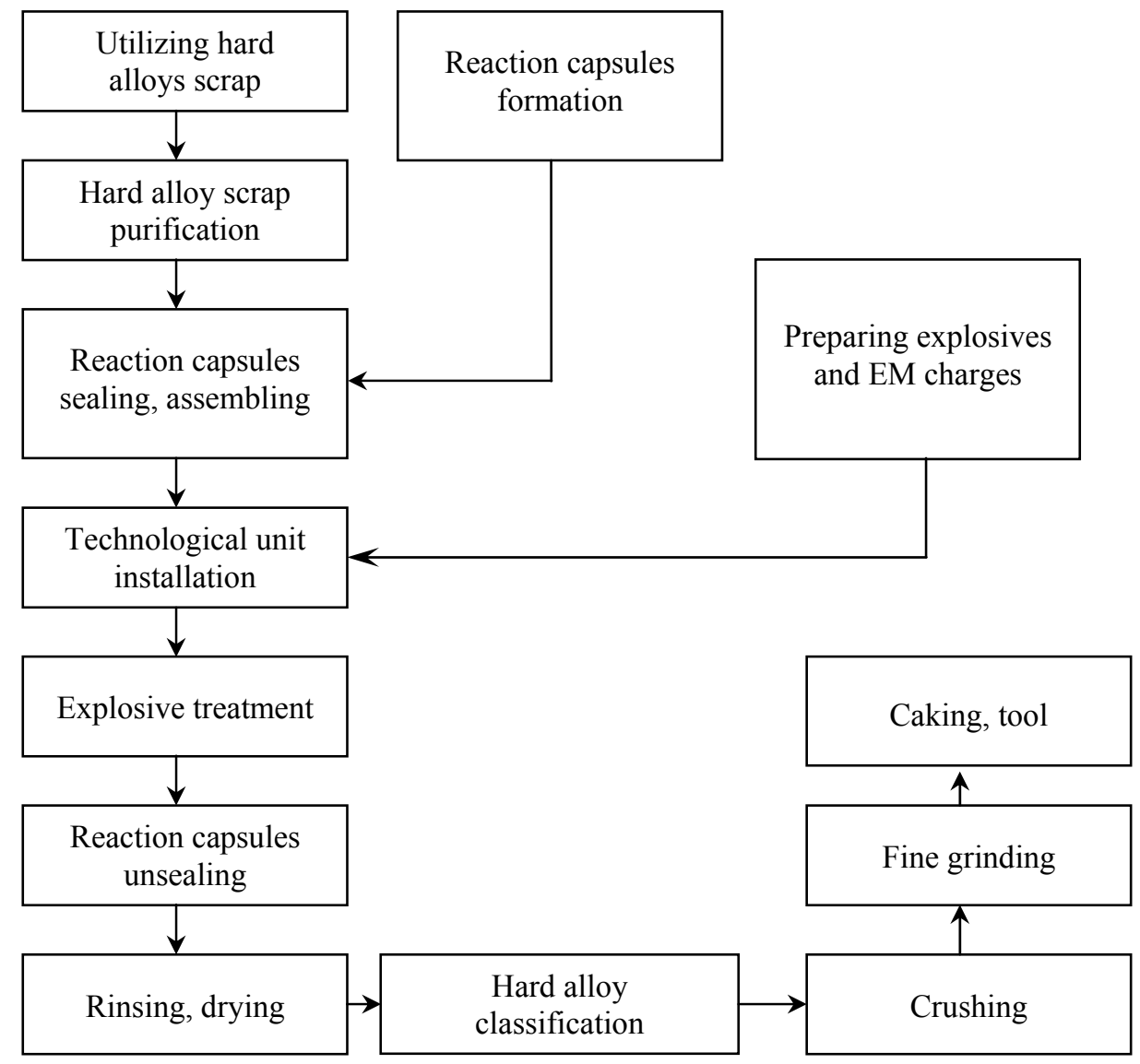

Figure 1. Technology of tungsten cobalt and tungsten nickel alloys regeneration

Thermochemical approach, which implies oxidizing scrap with consequent reduction and carbonizing of oxidized products, can be performed in different ways, which can be split into 2 groups: traditional technologies, which use black carbon for carbonization, and so called "non-black carbon" technologies, which anticipate carbonizing in methane hydrogen medium.
In both cases, oxidized product is being reduced in hydrogen, after which reduced powders are either being burdened with black carbon and carbonized in hydrogen or are being carbonized with help of methane hydrogen compound.

Nonetheless, mixtures of such compound do not guarantee stability of produced hard alloys with regards to 
carbon content. That is why in order to regulate the carbon content of produced powders, it is necessary to apply various approaches which complicate the technology by far.

Zinc method is based on the process when cobalt, tied into hard alloys, can be diluted in zinc at $600-800^{\circ} \mathrm{C}$, which leads to destruction of hard alloy product.

Ammunition was intensively engineered and produced both during war and peace times. Military warehouses and arsenal of the country have accumulated huge amount of such, out of which over 1.6 million tons are to be utilized (Shikunov, 1997). While outdated ammunition is of no use, its components, such as high quality metals, can be used effectively.

Highly effective technology of cutting, breaking and forming tools production from tungsten cobalt and tungsten nickel alloys by means of direct scrap regeneration, omitting the use of thermochemical and metallurgical methods was developed (Didyk, 1997; Schneider, 1999).

This technology is fundamentally different from the existing ones due to high technical and economical parameters, its productivity, low power consumption and ecological compatibility.

In practice, finished product results from a combination of technological channels of hard alloys utilization, preparation of reactive capsules, EM charges, regeneration, classification, fine grinding and caking (Fig. 1). Reduction of tungsten compound is performed under high gradient pressures and load speeds in the cylindrical reaction capsules, which undergo explosion treatment generated by the detonation of the axisymmetric charge of the explosive material (EM) (Fig. 2).

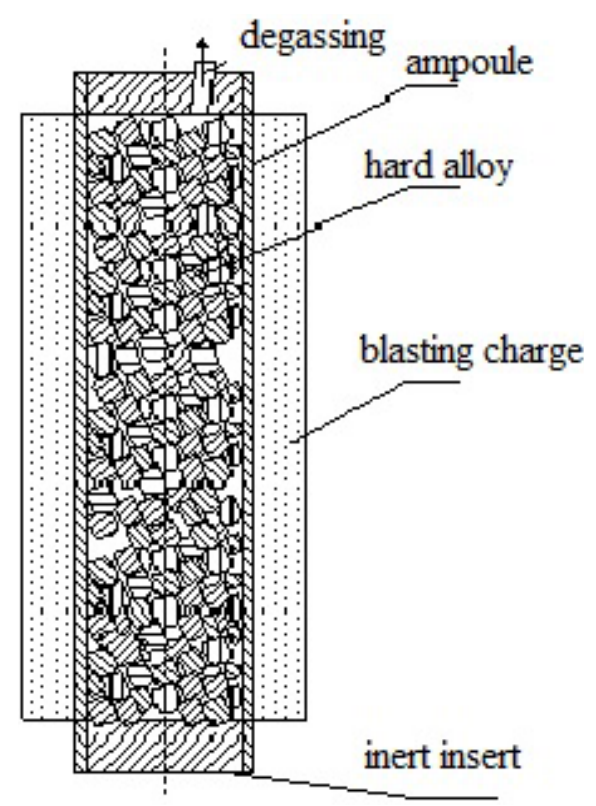

Figure 2. Capsule

Cermet alloys are such heterogeneous mixtures that contain in their medium surfaces on top of which any microscopic parameters can burst.

The results of known theoretical and experimental studies show that presence of components of different compressibility, density, and uneven distribution by volume cause significantly different nature of shock wave distribution compared to the shock wave distribu- tion in homogeneous compact mediums (Stanyukovich, 1971). It is necessary to note that contrary to the mechanical-thermal ways of impact, limited in both mechanical and physical-chemical effect, shock wave treatment causes structural changes at each large-scale level. Due to this, the idea of stimulating defect formation processes and chemical activation of tungsten alloys with shock waves has proved vital and productive (Savchenko, 2014; Savchenko \& Gurenko, 2014; Savchenko \& Verner, 2014; Savchenko \& Gurenko, 2016).

The conducted research into the effect of load on powder reactivity have shown significant increase in internal energy, which essentially accelerates powder compaction and caking processes. Besides, the growth of number and density of the defects (dislocations) leads to decrease in power consumption of the grinding process as a result of shock wave treatment.

Figure 3 contains data which illustrate the results of industrial testing of $\mathrm{WC}+\mathrm{Ni}$ powder wet grinding, after shock wave treatment. It also shows duration of powder grinding to the equal level of dispersion without shock wave pre-treatment.

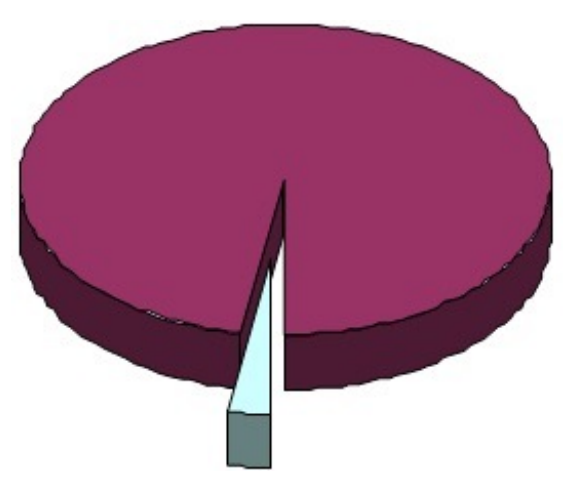

Figure 3. WC + Ni alloy grinding time: $\square$-shock-wave treatment; $\square$-without shock-wave treatment

The diagram clearly states that grinding of powder treated with shock waves takes 30 times less time in comparison to the existing grinding technology, which results in reduction of power consumption by $25-30 \%$.

Table 1 shows physical-mechanical properties of the new alloy produced from conversion scrap waste of $\mathrm{WC}+\mathrm{Ni}$ alloy. It is a two-phase alloy, $0.1 \%$ volume porosity, $\eta_{1}$-type phase is absent, the binder is evenly distributed, layer thickness is $0.5-1.5$ micron, uniform coarseness of $1-3$ microns with random grains up to 20.0 microns (Fig. 4).

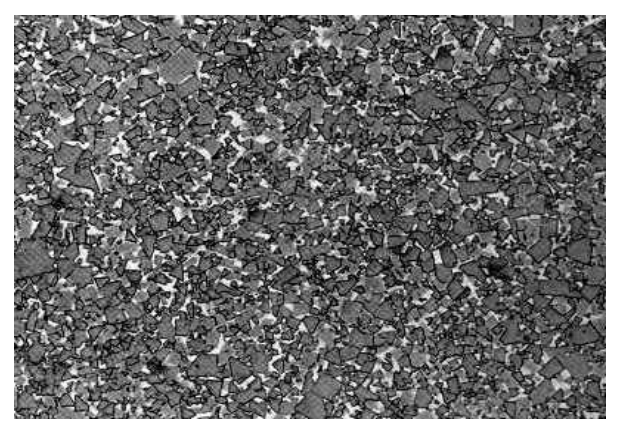

Figure 4. Microstructure of the alloy WNC, x400 
High effectiveness of the new technology was proved by industrial testing of ZR4-80 picks of $1 \mathrm{~K} 101 \mathrm{U}$ coal shearer executive screw members used for extracting coal from a seam of thickness $m=1 \mathrm{~m}$ and roof cut $m=0.43 \mathrm{~m}$ (sandy slate). 3150 tons of coal were extracted, using the experimental picks ZR4-80.

Table 1. Physical-mechanical properties of the alloy, produced by recycling of conversion scrap waste

\begin{tabular}{|c|c|c|c|}
\hline Grade of the alloy & Bending strength, $\mathrm{N} / \mathrm{mm}^{2}$ & Density, $\mathrm{g} / \mathrm{cm}^{3}$ & Hardness, HRA \\
\hline $\mathrm{WC}+\mathrm{Ni}$ & 1519 & 14.02 & 85.0 \\
\hline $\begin{array}{l}\text { New alloy WNC } \\
\mathrm{WC}+\mathrm{Ni}+\mathrm{Co}\end{array}$ & 1627 & 13.45 & 87.5 \\
\hline
\end{tabular}

Experimental picks had advantages over traditional ones, since no chipping and tearing of hard alloy cutting plate from the holder was observed. The consumption of experimental picks is $75 \%$ less than consumption of conventional picks produced in Ukraine and Russia. 38 RKS-1S picks were installed for testing in "Pavlohradska" mine on GPKS-1 shearer in the coalface of 551 tail gate of C5 seam. Development passage was performed through durain - clarain fusainized seam with coal strength 2 according to Protodiakonov scale, argillite, strength $-1.5-2.0$, soil - alevrolit, strength 1 , B-2 mm. PKC-1C picks operated in lava throughout 24 complete shifts. The main reason for the breakdown was complete abrasion of the insertions, tearing from the holder was not observed.

16 ZR4-80M picks were installed onto KA-85 shearer for testing in lava 555, C5 seam. Coal extraction was performed through durain - clarain fusainized seam with coal strength 3-4 according to Protodiakonov scale. ZR4-80M picks operated in lava throughout 24 complete shifts. The main reason for the breakdown was complete abrasion of the insertions, tearing from the holder was not observed. Based on the conducted studies, ZR4-80M picks have shown high quality results, operating time and can be recommended for serial production and usage.

Exporting high quality hard alloy scrap, Ukraine imports hard alloy tools at the same time, continuously increasing import volumes. This is explained by a large number of metallurgical, engineering and mining enterprises in Ukraine which are the main consumers of these tools.

The proposed project implies constructing of the unique center for utilization of super hard materials (tungsten, cobalt, molybdenum, nickel, tantalum) scrap in Ukraine, with production capacity of 60 tons of hard alloy powder a year. In future, it is reasonable to increase its capacity depending on the market demand.

Marketing strategy suggests offering international quality standard product at a price of $5-10 \%$ less than the market price.

The new technology is resistant towards negative factors. The center can operate at no loss, selling over 11 tons of products a year. In case of price drop by $10-20 \%$ or direct materials cost increase by $20-50 \%$, the output profitability will reach $60-70 \%$, which is still rather high.

Economical indices of the project are as follows:

- net present value (NPV) for the settlement period of project realization (5 years) is over 1265 thousand USD, which corresponds to the effectiveness condition, where NPV should be $>0$;

- investments profitability index (JR) - $6.0(\mathrm{JR}>1)$;
- recoupment of capital investments is 8 months from the issuance of the loan.

Industrial development of the above technology, within short timeframe, will allow to solve several important problems:

- hard alloys scrap utilization, its further reduction and consequent significant cut down on raw material usage;

- making use of new technology which omits low productive ways of scarce raw material utilization and manufacturing products of international quality standard;

- subsequent refusal from import in favor of hard alloy cermet tools;

- reduction and subsequent termination of strategic materials'and alloys scrap export from Ukraine, in favor of exporting ready products - powders and tools, which will increase foreign currency earnings of the country.

\section{CONCLUSIONS}

A comparative economic analysis of cermet alloys regeneration technologies was conducted. The study allowed to define fundamental potential of shock-wave treatment as a stimulating factor for destructing powder products of any configuration, in order to obtain high quality powder for further formation, caking and production of multiplepurpose tools. Environmentally friendly technology for recycling super hard materials, cermet components of outdated ammunition and different types of military equipment was suggested.

\section{ACKNOWLEDGEMENTS}

Scientific work is done in the framework of complex special purpose program "Organizing collection, utilization and recycling processes of hard alloys containing tungsten, tungsten scrap, molybdenum, cobalt and their alloys".

The authors extend their thanks to Rostyslav Didyk, Professor with the Department of Mining Engineering of the National Mining University.

\section{REFERENCES}

Didyk, R.P., Viunnyk, O.M., Hriaznova, L.V., Antsyferov, O.V., Savchenko, Yu.V., Pashchenko, M.I., Tubeliaeva, H.D., \& Masakovskyi, E.A. (2000). Sposib reheneratsii volframovmisnykh tverdykh splaviv. Patent No 15322, Ukraine.

Savchenko, Yu. (2014). Stvorennia burovoho instrumentu z vysokym resursom i vlastyvostiamy. In: Sovremennye innovatsionnye tekhnologii podgotovki inzhenernykh kadrov dlya gornoy promyshlennosti i transporta 2014 (pp. 295301). Dnipropetrovsk: Natsionalnyi hirnychyi universytet.

Savchenko, Yu., \& Gurenko, A. (2014). Ekonomicheskiy analiz tekhnologiy regeneratsii metallokeramicheskogo instrumenta. In: Razvitie informatsionno-resursnogo obespecheniya obrazovaniya i nauki v gorno-metallurgicheskoy otrasli i na 
transporte 2014 (349-354). Dnipropetrovsk: Natsionalnyi hirnychyi universytet.

Savchenko, Yu., \& Verner, I. (2014). Vysokoeffektivnyy instrument iz modifitsirovannogo tverdogo splava. In: Sovremennye materialy, tekhnika $i$ tekhnologii $v$ mashinostroenii (pp. 25-27). Dnipropetrovsk: Natsionalnyi hirnychyi universytet.

Savchenko, Yu., \& Gurenko, A. (2016). Ekonomicheskaya otsenka tekhnologii regeneratsii sverkhtverdykh materialov $\mathrm{s}$ ispol'zovaniem energii vzryva. In: Sovremennye innovatsionnye tekhnologii podgotovki inzhenernykh kadrov dlya gornoy promyshlennosti i transporta 2016 (pp. 215219). Dnipropetrovsk: Natsionalnyi hirnychyi universytet.

Schneider, A., Anciferov, A., Didyk, R., Savcenko, Ju., Vjunik, A., \& Masakovskij, E. (1997). Verfahren und einrichtung zur wiedergewinnung von harten legierungen und gesinterten materialien. Patent No WO 1997005295 A1, Germany.

Shikunov, V. (1997). Novaya zhizn' korpusov snaryadov. Voennyy parad, 7(1997), 37-39.

Stanyukovich, K. (1971). Neustanovivshiesya dvizheniya sploshnoy sredy. M: Nauka.

\section{ABSTRACT (IN UKRAINIAN)}

Мета. Провести порівняльний економічний аналіз технологій регенерації металокерамічних сплавів і вибрати найбільш “екологічно чисту” та рентабельну технологію переробки відходів твердих сплавів.

Методика. В якості методики дослідження для представленої роботи було проаналізовано кілька існуючих методів регенерації відходів вольфрамом кобальтових твердих сплавів: піро- й гідрометалургійний, хімічний (хлорний, цинковий), термохімічний та із застосуванням енергії вибуху бризантних вибухових речовин.

Результати. Проведено порівняльний економічний аналіз технологій регенерації металокерамічних сплавів.

Наукова новизна. Показана принципова можливість використання ударно-хвильової обробки як фактора, що стимулює процеси руйнування порошкових виробів будь-якої конфігурації, з метою отримання високоякісного порошку для подальшого формування, спікання й виробництва інструменту різного призначення; запропоновано екологічно чисту технологію переробки надтвердих матеріалів, металокерамічних складових застарілої військової техніки та різних видів боєприпасів.

Практична значимість. Промислове освоєння розробленої технології дозволяє вирішити наступні проблеми:

- утилізацію лому надтвердих матеріалів і сплавів з їх подальшим відновленням і відповідно значною економією стратегічної сировини;

- використання нової технології з виключенням вживання малоефективних способів переробки дефіцитної сировини і випуск продукції світового рівня якості;

- поступова відмова від імпорту у бік твердосплавного металокерамічного інструменту;

- зменшення, а потім і відмова, від експорту за межі України лому стратегічних матеріалів і сплавів, 3 переходом до експорту готових виробів-порошків та інструменту, що значно збільшить валютні надходження в країну.

Ключові слова: вольфрам, кобальт, інструмент, твердий сплав, металокераміка, переробка відходів, гетерогенна середа, дефект утворення

\section{ABSTRACT (IN RUSSIAN)}

Цель. Провести сравнительный экономический анализ технологий регенерации металлокерамических сплавов и выбрать наиболее “экологически чистую” и рентабельную технологию переработки отходов твердых сплавов.

Методика. В качестве методики исследования в настоящей работе были проанализированы несколько существующих методов регенерации отходов вольфрамом кобальтовых твердых сплавов: пиро- и гидрометаллургический, химический (хлорный, цинковый), термохимический и с применением энергии взрыва бризантных взрывчатых веществ.

Результаты. Проведен сравнительный экономический анализ технологий регенерации металлокерамических сплавов.

Научная новизна. Показана принципиальная возможность использования ударно-волновой обработки как фактора, стимулирующего процессы разрушения порошковых изделий любой конфигурации, с целью получения высококачественного порошка для дальнейшей формовки, спекания и производства инструмента различного назначения; предложена экологически чистая технология переработки сверхтвердых материалов, металлокерамических составляющих устаревшей военной техники и различных видов боеприпасов.

Практическая значимость. Промышленное освоение разработанной технологии позволяет решить следующие проблемы:

- утилизацию лома сверхтвердых материалов и сплавов с их последующим восстановлением и соответственно значительной экономией стратегического сырья;

- использование новой технологии с исключением употребления малоэффективных способов переработки дефицитного сырья и выпуск продукции мирового уровня качества;

- постепенный отказ от импорта в сторону твердосплавного металлокерамического инструмента;

- уменьшение, а затем и отказ, от экспорта за пределы Украины лома стратегических материалов и сплавов, с переходом к экспорту готовых изделий - порошков и инструмента, что значительно увеличит валютные поступления в страну.

Ключевые слова: вольфрам, кобальт, инструмент, твердый сплав, металлокерамика, переработка отходов, гетерогенная среда, дефектообразование 


\section{ARTICLE INFO}

Received: 9 September 2016

Accepted: 14 December 2016

Available online: 30 December 2016

\section{ABOUT AUTHORS}

Iurii Savchenko, Senior Lecturer of the Department of Mining Engineering, National Mining University, 19 Yavornytskoho Ave., 4/26, 49005, Dnipropetrovsk, Ukraine. E-mail: SavchenY@ua.fm

Anna Gurenko, Manager, LLC "VF Consulting Services", 60 Kyrylivska St, 04080, Kyiv, Ukraine. E-mail: AnnaG@vfsglobal.com

Olena Naumenko, Senior Lecturer of the Department of Structural, Theoretical and Applied Mechanics, National Mining University, 19 Yavornytskoho Ave., 3/7, 49005, Dnipropetrovsk, Ukraine. E-mail: Elena_Naumenko71@mail.ru 